\title{
Sangue \\ [a jeito de testemunho]
}

[à minha mãe]

Num dia de maio de um dos últimos anos, pouco após o alvor, no Jardim da Estrela, vi um gato correr com um pássaro arrebatado nas mandíbulas para lugar a cobro da inspeção humana e da concorrência animal. O estertor próximo, do focinho do felino sobressaíam as asas eretas e imóveis da pequena ave. Não interferi. Há muito que me pacificara diante da angústia da morte.

Em rigor, comecei a pacificar-me assim que, dois dedos de gente, me confrontei com a morte. Minha mãe secou-me a angústia na transformação da morte num elemento do ciclo da vida. Explicou que, dos bichinhos pequenos e simples que vivem na terra que se cibam de restos mortais e corpos sem vida aos animais grandes e complexos como as pessoas humanas, forma-se uma longa cadeia de seres vivos transformados dos zoontes imediatamente antecedentes da cadeia que não poderiam existir acaso a morte não fosse. Morte, então, não fim, mas estádio de vida prestes a modificar-se. Quanto penou por isso. Durante seis meses, consumi-lhe o génio trazendo-lhe todos os bichos cessados que encontrava para que procedesse ao funeral devido. Insetos e aracnídeos, pequenos répteis e mamíferos, todos a serem postos na terra dentro de um recipiente adequado para que pudessem evoluir para novas formas de vida. Mais tarde complicou-se-me esta versão mágica da integração pela morte de todos os seres no ciclo contínuo da vida, mas nunca perdi o sentimento de paz que infundiu em mim.

Provei a primeira grande prova desta pax perpetua em Bombaim. Em 1986 Mumbai ainda era Bombaim. Foi lá que, não muito longe da Porta da Índia, uma menina que corria descalça estrebuchou nos meus braços, ambos ensopados do sangue que jorrava em golfos do seu crânio escacado, antes de se aquietar. Açodava atrás de um rickshaw que levava um casal de jovens pálidos e louros e muito tocados pelo infortúnio dos intocáveis. Acabou colhida por um carro que seguia velozmente. Teria nove anos, doze, entre. Só voltei a ver a vida a fugir da vida anos mais tarde quando levámos E. ao doutor das outras pessoas para lhe pôr fim à agonia e à nossa aflição, a vasca vinda em decúbito ventral calorosa do meu corpo. Desde Bombaim que sabia que a morte pode realmente reparar. Tal e qual a empatia com todas as formas de vida que afeiçoam à vida e tantas vezes perseguimos e exterminamos por medos 
obtusos. Como os geconídeos que minha mãe - era eu pirralho - me instruiu, a contrapelo da crença popular que lhes atribui qualidades peçonhentas, que são aliados milagrosos contra os hematófagos que com afinco invejável nos precingem, atormentam e chagam mal o inverno termina.

Ao romper do dia das últimas chuvas deste verão, dei precisamente com uma osga-moura no lanço de escadas à saída de casa. Às avessas, inerte, a cabeça triangular e o fole amarelado patentes, gotejados copiosamente. Não estava deformada, nem ferida, só feita da feição categórica da morte. Munido de plástico de dimensão certa e pequena vassoira, preparei-me para lhe dar destino de detrito orgânico. Mexeu-se. Pouco, bastante. Não me entusiasmei. Cri que agonizava. Como se só pudesse reviver. Com uma velha espátula de madeira virei-a trazendo vagar, delicadamente. Linda de morrer, com as suas escamas amarfinadas raiadas por matizes fulvos e glaucos, pousou e quedou-se. Menos de não saber para onde ir que da dormência que a expunha à natureza, ao predador e ao treino da criança. Tomei azo a decidir que fazer. Faltou-me cor e pulso para a compaixão, para desferir o golpe de misericórdia. Empurrei-a para uma pá em cuja face fixou as ventosas dos membros arqueados, exauridos. Transportei a pá e a sua ocupante até um telheiro. Não estava frio, lá a chuva não a atormentaria. Isto foi de dia e enquanto foi noite pensei que a manhã me traria luz e cadáver e culpa e que poderia enfim acabar o que começara na véspera. À guarda da índole e do esplendor comum, batizara-a Olga. A manhã, porém, não me trouxe paradeiro. Foi a criatura silvestre, ficou a alegria breve e um fulgor de vida inolvidável.

"É impossível viver sem esquecer," sentenciou Nietzsche. Estarei hoje, circunstância de tréguas à irreparável perda, cerca desse ponto de esgotamento da vontade vital por onde vazam as memórias-écran que ocultam o que sabemos e não toleramos saber de que falava o Freud. A memória como biografia piedosamente adulterada pela sua própria inscrição discursiva. Grotescamente, porque o grotesco idealiza:

\author{
Guiada pela humidade \\ a raiz enraíza \\ onde proliferam \\ fungos mortais.
}

Quando posso, e posso muito, escuso pessoas, não atos, negligências, faltas capitais, hesitações e indecisões criminosas, coisas de que fui sujeito; coisas de que hoje, espartilhado por forças morais que não controlo, sou objeto de duros e implacáveis golpes de memória. Por mais que queira e pudesse e me seja insuportável lembrar não consigo esquecer. Esquecer equivaleria ao débito absoluto, a congelar a fragilidade na fleuma. Não é solução. Não há indiferença emocional inofensiva. Mesmo quando a memória é das fezes da D. Irene a escorrer pela parede e de lascas de alho debaixo das unhas na enfermaria dos indigentes. Dizia o Walter Benjamin, equacionando-a como efeito narrativo, que a memória é a mais épica das faculdades. É a forma de ver as coisas que, sem dúvida, me convém neste momento. Outra acentuaria o seu cariz ilu- 
sório. Virá a dar no mesmo. Pelo Stendhal, sei que se me mura a inocência: Il ne faut pas prétendre à la candeur, cette qualité d'une âme qui ne fait aucun retour sur elle-même. Pela nossa experiência comum, sei que nas entranhas da subjetividade germinam extraordinárias sinestesias.

Torno à evocação, desta vez aos dois, antre nós, presentes no presente de um diário com escassas entradas.

3 de abril, início da primavera. Fim de tarde inusitadamente bafejado por ar quente e seco. A luz carminada do dia ao longe côa no copo sobre a mesa, orlando o milhafre que aproveita as fortes correntes verticais ascendentes geradas pela baixa pressão térmica para planar escassos metros acima do solo e de nós. Na linha da emoção extraordinária, por perto um gato de pelo farto e focinho e bojo de fêmea foge do artifício felino do ser humano que se julga capaz de convir a todos os seres vivos, simples e complexos. O gato vai para a via rápida onde veículos de cilindradas desiguais aceleram e trucidam insetos e pequenos mamíferos. Vemo-lo atravessá-la e desaparecer ileso do lado de lá. Retomamos as fístulas tangíveis e intangíveis do Lowry, debaixo do vulcão. Agora com o Cardoso Pires que, agravado pelas escórias salubres, estremava a mediania humana na asserção severa não sabem gastar-se. Volto a retrair-me. Será possível livrar alguém chegado dos seus demónios sem soltar os próprios? Estamos ainda longe de casa e demasiado combalidos para procurar abrigo. A história repete-se. Não há digressões plácidas pelas relações vitais. Estais irreversivelmente velha, mãe? Ao que ripostou: "mau era que, desperta já para a disposição testamentária, não soubesse que tantas vezes as chaves lexicais que nos resgatam da realidade nua e crua são as que, catadas vivas, contemos. O tormento só vem depois quando, privadas da banalidade que pulsa no seu uso espontâneo, se convertem em espectros absorventes que pontificam a safra ficcional. Pois é. O meu paradeiro ontológico compõe-se no mais assombrado dos modos indicativos: o condicional levou-me anos de vida antes mesmo de me deixar irreconhecível. Em chegando a velha, como vou chegando, há apenas que repelir as criaturas adventícias que vigiam a decadência."

Importará a contradição? Se o declínio é frisado pela vigilância que lhe emprestamos porquê insistir em narrar como histórias translatícias sobre a família duas histórias trágicas de figuras masculinas, a do Gomes Freire e a do Sancho, morgado? "Nunca olhámos o desastre ou o fiasco de través," declarou, dissidentemente subvertendo o enigma na fusão de eros e tânatos, da pulsão de vida na pulsão de morte. Histórias breves na matriz, que providenciam afinal guarida e talhe e não tomam muito tempo a contar.

Sentenciado à morte, Gomes Freire desejava que, de acordo com as honras militares devidas a um veterano da guerra, a morte lhe chegasse por saraivada de um pelotão de fuzilamento a que ele mesmo desse voz de fogo. Não foi assim. Subiram-no ao patíbulo e enforcaram-no.

Sancho casou com Maria dos Anjos, prima direita que lhe deu um só filho, degenerado e avesso ao privilégio. Um inútil. Ainda o corpo da mulher não arrefecera, aparelhou o cavalo, tomou a estrada de macadame até à casa do rendeiro e, sem pedir licença, mas com uma abnegação que disfarçava mal a falta de viço sexual, serviu-se de Delfina, a senhora da casa. Estavam de caso interrompido desde que a doença de Maria dos Anjos chegara à fase da agonia. Delfina não tinha ilusões de substituir Maria dos Anjos. Aceitara tornar-se amante de 
um homem que não a queria por compaixão. Um homem que matou a mãe à nascença é para sempre um aleijado. Nele, felicidade e falicidade jamais serão formações psíquicas compatíveis. E que haveria de ter dado motivo ao poema carnal.

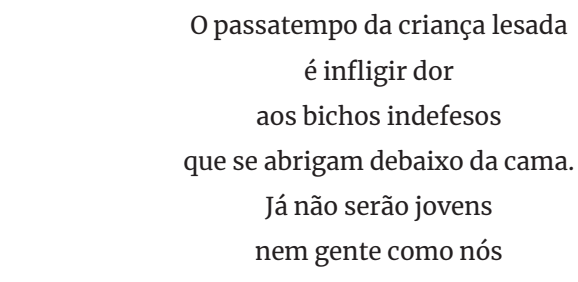

[que fabrica monstros e empresas igualmente maravilhosas] as carcaças prestáveis deitadas ao lixo.

"Implacável, implacável, só perante a cobardia." Ainda acrescentou, por fim, a fim: "a Ressurreição não é nada à Paixão," criando vau para que contrapusesse, numa voz íntima calhada a frear a aspereza e o júbilo do sobrevivo, uma espécie de consolatio avant la peine: "a mim e a todos os seus nunca nos faltará loci inamoeni dispersos por extensas sáfaras para desbravar."

E veio-me o prodígio materno - que já se faz tarde a citação e o almoço - a dar graças à fábula da rã e do escorpião:

"- Como é isto possível, que comigo te findas?

- É o meu carácter, diz ele sublinhado, sorriso sabido e, 'Viva a morte', que é o brado da espécie."

Quando o luto vier, poderei quiçá despertar do estupor precavendo-me de pastorear as coisas da vida e da morte no grande drama da morte e no princípio flexíloquo da sucessão - le mort saisit le vif - encalçando sem bravata ou resistência o movimento telúrico da animação de todos os meus outrora-vivos, imensos e módicos. E dos que vêm e virão quando, na administração do dia-a-dia, sobrevém a preservação animal. Andam ratos cá em casa a passear-se e não pode ser. Armarei a ratoeira. É a solução humana, compassiva. Parte-se-lhes o pescoço e é morte imediata, santa. Não andam umas horas, uns dias a romper-se por dentro com químicos. A bênção, minha mãe. 